\title{
Impact of Cover Crops on Soil Quality Parameters of Coconut (Cocos nucifera L.)-Grown Red Yellow Podzolic Soil
}

\author{
H. M. I. K. Herath ${ }^{1 *}$, H. M. Silva ${ }^{2}$, P.G. Synthya ${ }^{3}$ and L. P. Vidhana Arachchi ${ }^{2}$
}

\begin{abstract}
Degradation of soil quality as a result of the long-term coconut cultivation is a challenge for sustainable coconut production. This study was conducted to assess the changes in soil quality of coconut-grown Red Yellow Podzolic soil under two widely grown cover crops of Puereria phasioloides (Fabaceae) and Brachiaria brizantha (Poaceae) compared to coconut land with no cover crop (control). Coconut lands were located in the low country intermediate zone- $\mathrm{IL}_{1}$ of Sri Lanka. The soil samples were collected and analyzed for physical, chemical and biological properties. Results indicated that the soils from coconut cultivation with $\boldsymbol{P}$. phasioloides were superior in most of the properties compared to those of $B$. brizantha and the control. Soil from coconut land with $P$. phasioloides was significantly higher in, electrical conductivity, organic carbon content $(0.66 \%)$, number of bacterial colonies $\left(19.76 \times 10^{6} \mathrm{CFU} / \mathrm{g}\right)$ and microbial activities (1.55 mg CO$/$ day). There were no significant differences between top soil $(0 \mathrm{~cm}$ $-11 \mathrm{~cm})$ and sub soil $(11 \mathrm{~cm}-42 \mathrm{~cm})$ for $\mathrm{pH}$, electrical conductivity and organic carbon. Soils under $P$. phasioloides and $B$. brizantha showed higher aggregate stability and low bulk density compared to control. Water availability at the field capacity was higher $(32.98 \%)$ in soils under $B$. brizantha in the
\end{abstract}

\footnotetext{
${ }^{1}$ Department of Plantation Management, Faculty of Agriculture \& Plantation Management, Wayamba University of Sri Lanka, Gonawila 60170, Sri Lanka

${ }^{2}$ Department of Export Agriculture, Faculty of Agricultural Sciences, Sabaragamuwa University of Sri Lanka, Belihuloya, 70140. Sri Lanka

${ }^{3}$ Soils \& Plant Nutrition Division, Coconut Research Institute, Lunuwila, 61150, Sri Lanka

*indikaherath@hotmail.com
}

$(32.98 \%)$ in soils under $B$. brizantha in the top soil. The study revealed that as a cover crop $P$. phasioloides has a higher potential in improving soil qualities in coconut lands.

Keywords: Coconut cultivation, Cover crops, Soil health, Soil properties

\section{INTRODUCTION}

The annual coconut yield in Sri Lanka has shown considerable fluctuations with a generally declining trend over generations mainly due to variations in major climatic parameters and properties of soils. The nutritional status of soil is deteriorating due to continuous cultivation, poor management practices and improper soil and nutrient management. Degradation of soil quality as a result of the long-term coconut cultivation has been recognized as a challenge for sustainable coconut production.

Generally, the fertility of coconut soils in Sri Lanka is poor due to the continuous removal of soil nutrients by palm products such as nuts, husks, shells, sap, and falling fronds (Tennakoon, 1990). Therefore, coconut growing soils in Sri Lanka are generally deficient in total, active and available forms of phosphorus and some other nutrients (Loganathan et al., 1984; Jayakody et al., 2007).

Cover cropping is a key management 
practice which improves soil properties, reduces soil degradation and improves productivity. It is the practice of introducing plants with dense foliage as groundcovers under the plantation crops. Artificially established covers have more uniform nature in agriculture than the natural forests (De Silva, 1961). Nevertheless, growers are reluctant to integrate a cover crop due to some difficulties in field operation and maintenance.

Most groundcovers can be divided into two cover crop orders Poaceae (cereals and grasses) and Fabaceae (leguminous plants). These plants need to have certain characteristics which make them exclusively suitable for cover-cropping. The major cover crops recommended for coconut lands in Sri Lanka are, Pueraria phaseoloides ('Puero'), Calopogonium mucunoides ('Calopo'), Centrosema pubescens ('Centro') and bush cover crops such as Gliricidia sepium ('Weta-mara') (Coconut Research Institute, 2012). Selection of appropriate groundcovers and their management warrants substantial experience and skills.

Although cover cropping improves soil physical, chemical and biological properties, quantification of soil quality improvements under different cover crops needs investigation. Therefore, the present study was conducted to assess the improvement of soil quality in coconut plantations in the intermediate zone (major soil type: Red Yellow Podzolic) of Sri Lanka with two widely grown cover crops of Puereria phasioloides and Brachiaria brizantha compared to coconut mono crop system with no cover cropping.

\section{METHODOLOGY \\ Treatments and Sampling}

The experiment was conducted in coconut plantations in the low country intermediate zone of Sri Lanka. Soil type was gravelly and classified as the Andigama soil series (Typic Troporthents, shallow, fine loamy, non-calcareous, isohyperthemic) (Mapa et al., 2005) belonging to the great soil group Red Yellow Podzolic.

The three treatments were, T1Established cover crop Puereria phasioloides (Family Fabaceae) under coconut cultivation, T2- Established cover crop Brachiaria brizantha (Family Poaceae) under coconut cultivation and T3Normal coconut land without cover crops. The coconut palms were 15-20 years old and the study was conducted four years after the establishment of cover crops.

Soil samples were collected from three randomly selected locations in each site to represent each cultivation system. Samples were obtained from the centre of the square between coconut palms and analyzed for chemical, physical and biological properties. Samples for soil chemical properties, soil bulk density and soil water retention were collected from two depths, namely, A soil horizon $(0-11 \mathrm{~cm})$ and $A B$ horizon $(11-42 \mathrm{~cm})$ at each sampling location.

Samples for the determination of 
biological properties were taken by extracting $15 \mathrm{~cm} \times 15 \mathrm{~cm} \times 11 \mathrm{~cm}$ soil layer which was cut from the A soil horizon and it was placed into labeled transparent polyethylene bags. The samples were stored in refrigerator $\left(4-5{ }^{\circ} \mathrm{C}\right)$ until taken for analyses.

\section{Determination of Soil Physical Properties}

Bulk density of soil samples was determined as described by Blake and Hartge (1986). Soil dry aggregate stability was determined as described by Nimmo and Perkins (2002), dry-sieving method was used for the determination of aggregate size distribution. Minimally disturbed air dried soil samples were used for the analysis and Mean Weight Diameter (MWD) as the indicator of dry aggregate stability was calculated as below.

Mean Weight Diameter $($ MWD $)=\sum$ XiWi

Where,

$\mathrm{Xi}=$ Mean diameter of size fraction

$\mathrm{Wi}=$ Proportion of total sample retained on sieve

The water retention at field capacity was determined using the pressure plate apparatus at 0.1 bar pressure and soil cores with samples were kept $48 \mathrm{~h}$ in an oven at $105{ }^{\circ} \mathrm{C}$ to get the dry weight.

\section{Determination of Soil Chemical Properties}

Electrical conductivity (EC) of the soil samples were determined in a 1: 2.5 (Soil: Water) suspension and EC values were measured using a conductivity bridge (Orion 145A+). Soil $\mathrm{pH}$ values were measured using a calibrated Orion $310 \mathrm{pH}$ meter. Soil organic carbon (OC) was determined using the modified wet digestion - Walkley-Black method (Nelson and Sommers, 1982).

\section{Determination of Soil Biological Properties}

Samples were taken out from the refrigerator and kept one hour before performing the analyses at room temperature $\left(28^{\circ} \mathrm{C}-30^{\circ} \mathrm{C}\right)$. The number of bacterial colonies [colony forming units $(\mathrm{CFU})]$ and fungal colonies were enumerated by Spread Plate count method (Anderson and Ingram, 1989). Respiration rate $\left(\mathrm{CO}_{2}\right.$ evolution) was quantified considering the released carbon dioxide gas of living organisms and it was calculated by $\mathrm{CO}_{2}$ evolution method to determine microbial activity (Anderson and Ingram, 1989).

\section{Experimental Design and Data Analysis}

Analyses were performed on three replicate samples obtained from each experimental site. All data on soil physical, chemical and biological properties were analyzed by one way analysis of variance (ANOVA) with Turkey's test using Statistical Analysis System (SAS) software.

\section{RESULTS AND DISCUSSION}

Changes in soil quality in terms of soil physical, chemical and biological 
parameters, among the three cultivation systems show a variation in relation to different parameters tested as indicated below.

\section{Soil Physical Properties \\ Bulk Density}

The bulk density of soil samples obtained from different depths are shown in Table 1. Control (No cover crop) system had a relatively higher bulk density $(1.55-1.58$ $\mathrm{g} / \mathrm{cm}^{3}$ ) while the Coconut + Pueraria phaseoloides system had a lower bulk density $\left(1.52-1.55 \mathrm{~g} / \mathrm{cm}^{3}\right)$. Pueraria phaseoloides adds a high amount of organic matter which can organize soil mineral particles into structural units that improve soil porosity. However, there was no significant difference in bulk density between treatments $(\mathrm{p}>0.05)$.

\section{Dry Aggregate Stability}

Coconut-grown soils in Coconut $+P$. phaseoloides and Coconut $+B$. brizantha systems showed significantly $(\mathrm{p}<0.05)$ higher mean weight diameter (MWD) compared to the control (Figure 1). Brachiaria brizantha had the highest aggregate stability indicated by the highest MWD of 1.78 which could be due to enhanced aggregation caused by the fibrous root mat of Coconut $+B$. brizantha grass system. A higher stability of aggregates protects soil from the impact of rain drops and reduce run-off by increasing the surface infiltration. Soils with stable aggregates tend to have better soil tilth, greater water infiltration, and better aeration for crop growth (Hoorman, 2009).

\section{Water Availability at Field Capacity}

Water availability of soil at field capacity slightly varied across different cover crop systems of coconut (Figure 2). However, there was no statistically significant difference among the treatments for water retention.

There was a slightly lower water availability at field capacity in Coconut $+P$. phaseoloides system compared to other two treatments. Its water availabilities at field capacity at $11-42 \mathrm{~cm}$ (depth 2) and $0-11$ $\mathrm{cm}$ (depth 1) depths were $28.93 \%$ and $28.05 \%$, respectively. Such variation, albeit low, could be attributed to the deep root system, increased aggregate stability and pore spaces. On the other hand, in Coconut + B. brizantha system, soil water availability at depth 1 was higher $(32.98 \%)$ than that of depth $2(28.50 \%)$ possibly due to fibrous root system which help retain the surface moisture.

\section{Soil Chemical Properties}

Chemical properties of soils play a key role in the productivity of coconut lands and are therefore, considered as important indicators of soil quality changes.

\section{Soil pH}

The $\mathrm{pH}$ values were significantly $(\mathrm{p}<0.05)$ different between the control and Coconut + $P$. phaseoloides treatment. However, there was no significant difference between 
Table 1. Mean soil bulk density of different coconut + cover crop systems

\begin{tabular}{lcc}
\hline \multicolumn{1}{c}{ Treatment } & Depth $\mathbf{1} *\left(\mathbf{g} / \mathbf{c m}^{\mathbf{3}}\right)$ & Depth $\mathbf{2} * *\left(\mathbf{g} / \mathbf{c m}^{\mathbf{3}}\right)$ \\
\hline Coconut + Pueraria phaseoloides & 1.55 & 1.52 \\
Coconut + Brachiaria brizantha & 1.57 & 1.53 \\
Control (No cover crop) & 1.58 & 1.55 \\
\hline
\end{tabular}

*0 -11 cm;**11-42 cm

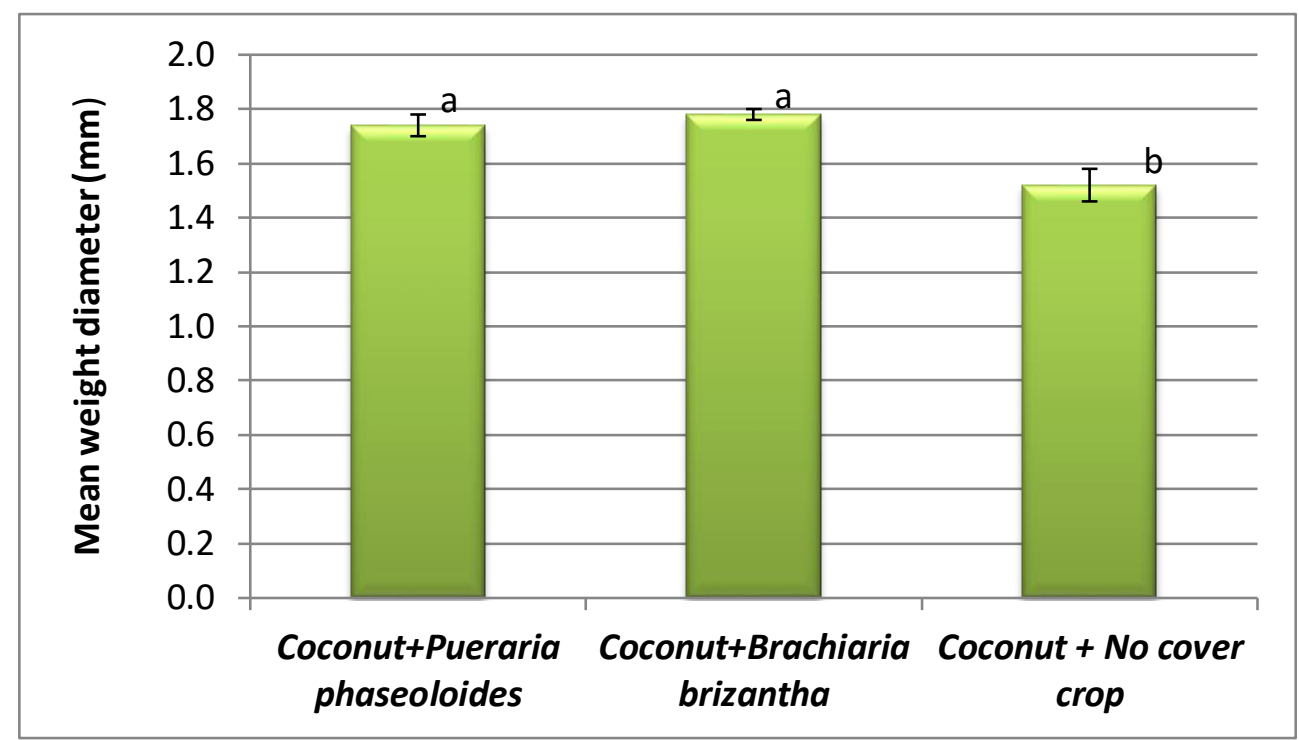

Figure 1. Mean weight diameter of different coconut + cover crop systems Mean values indicated by same letters are not significantly different

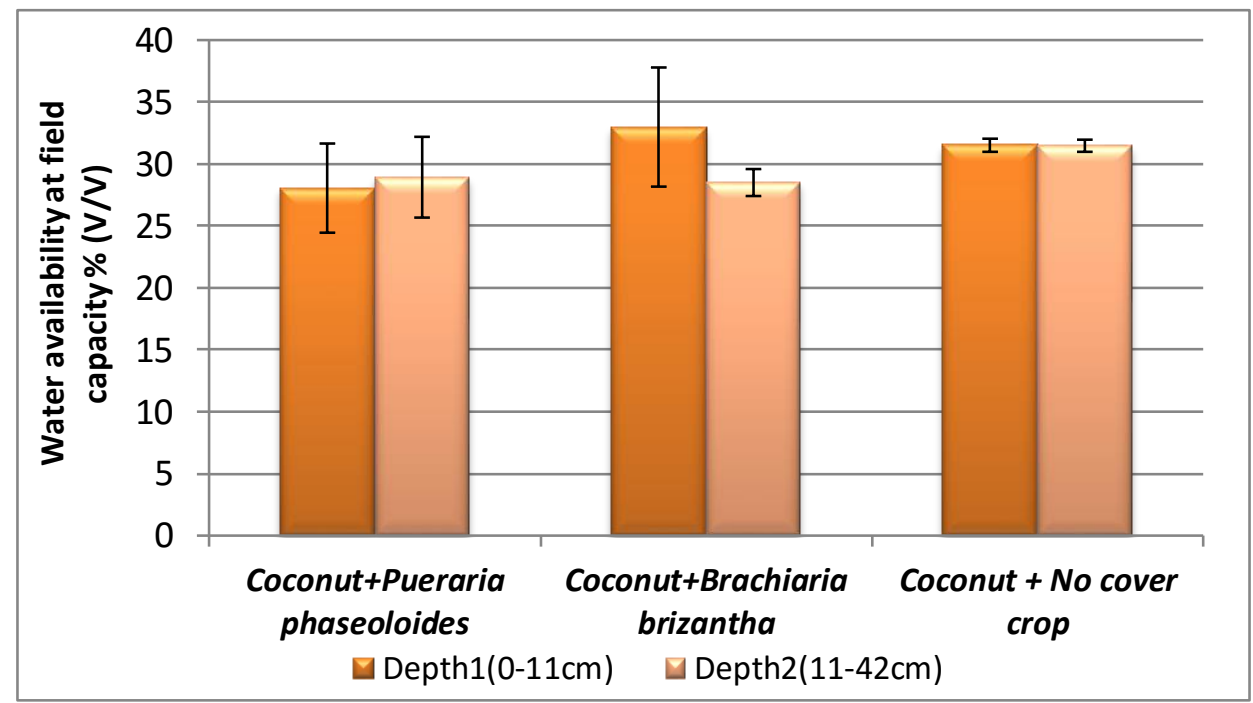

Figure 2. Water availability of soil at field capacity under different coconut + cover crop systems 
Control and Coconut $+B$. brizantha treatments (Figure 3). In all three systems, $\mathrm{pH}$ values were higher in top soil than in sub soil. The reason may be that when the exchangeable bases are leached down to lower layers of soil, the exchange sites are taken up by $\mathrm{H}^{+}$ions. However, the soil $\mathrm{pH}$ of these localities apparently fall within the favourable range for coconut cultivation.

\section{Electrical Conductivity (EC) of Soil}

Electrical conductivity in the soils of Coconut $+P$. phaseoloides and Coconut + $B$. brizantha systems was significantly $(p<0.05)$ higher than that of the control (Figure 4). Soils from Coconut $+P$. phaseoloides system had the highest EC value of $43.70 \mu \mathrm{S} / \mathrm{cm}$. It could be due to a higher amount of decomposing biomass in the top soil. The EC at depth $1(0-11 \mathrm{~cm})$ was higher than the EC at depth $2(11-42$ $\mathrm{cm})$ in all treatments. It could have been caused by the salts from various sources, including fertilizer, which accumulate in the top soil as the water evaporates from soil surface. Less rainfall in the intermediate zone may have further intensified the salt accumulation in top soil.

\section{Soil Organic Carbon (OC) Content}

There were significant differences $(\mathrm{p}<0.05)$ in organic carbon percentages of soils from different coconut - cover crop systems (Figure 5). The Coconut $+P$. phaseoloides system had the highest OC content of $0.66 \%$ because of its high biomass production, followed by the Coconut $+B$. brizantha system which had a mean OC content of
$0.63 \%$. The OC contents of cover cropgrown soils were significantly higher than that of control $(0.40 \%)$ which indicates that cover crops have improved the OC content of soil. In all three systems, soils from depth 1 showed a significantly $(\mathrm{p}<0.05)$ higher OC content compared to that of depth 2 . It could be due to accumulation of crop residues on the soil surface compared to the deeper layers which is a common phenomenon observed in many agricultural soils.

\section{Soil Biological Properties Soil Bacterial Population}

The numbers of bacterial colonies from soil samples varied significantly $(\mathrm{p}<0.05)$ among the treatments (Table 2). Coconut + $P$. phaseoloides system had the highest significant soil bacterial count of $19.765 \times 10^{5} \mathrm{CFU} / \mathrm{g}$ due to high amount of organic carbon in the top soil. The bacterial colony counts of soils from Coconut $+B$. brizantha and control were also significantly different.

Organic matter and humic substances facilitate bacterial growth. As a result, highly decomposed types of organic matter produced by bacteria improve the stability of larger aggregates and thereby, enhance the quality of soil making it favourable for agriculture.

\section{Soil Fungal Population}

A relatively higher number of fungi colony forming units (CFU) was observed under Coconut $+P$. phaseoloides system 


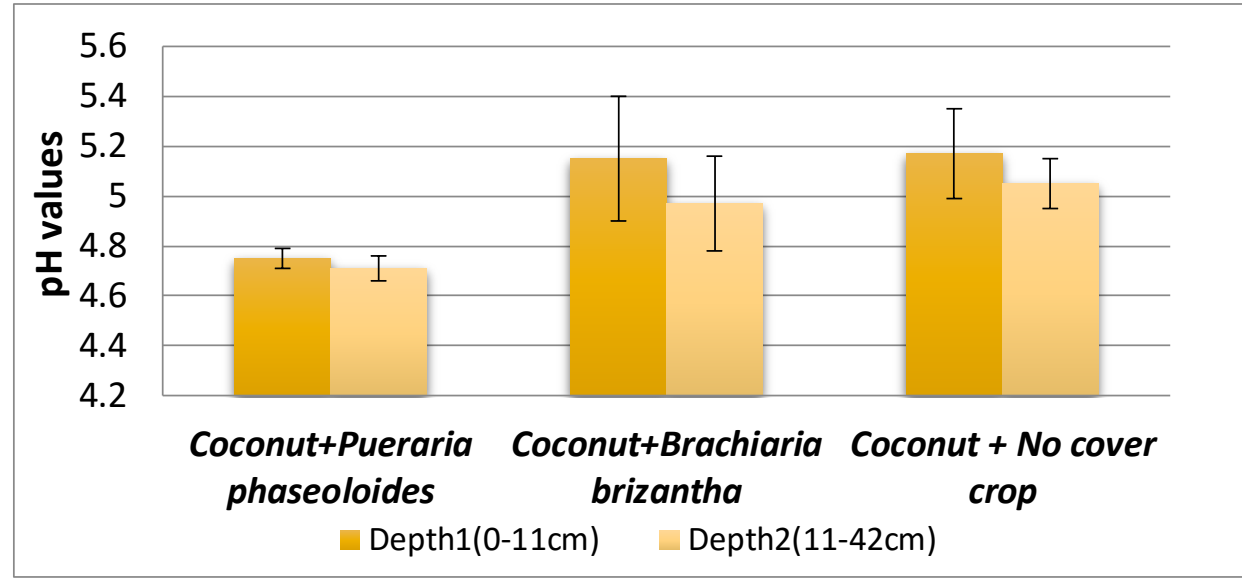

Figure 3. Soil $\mathrm{pH}$ under different coconut + cover crop systems

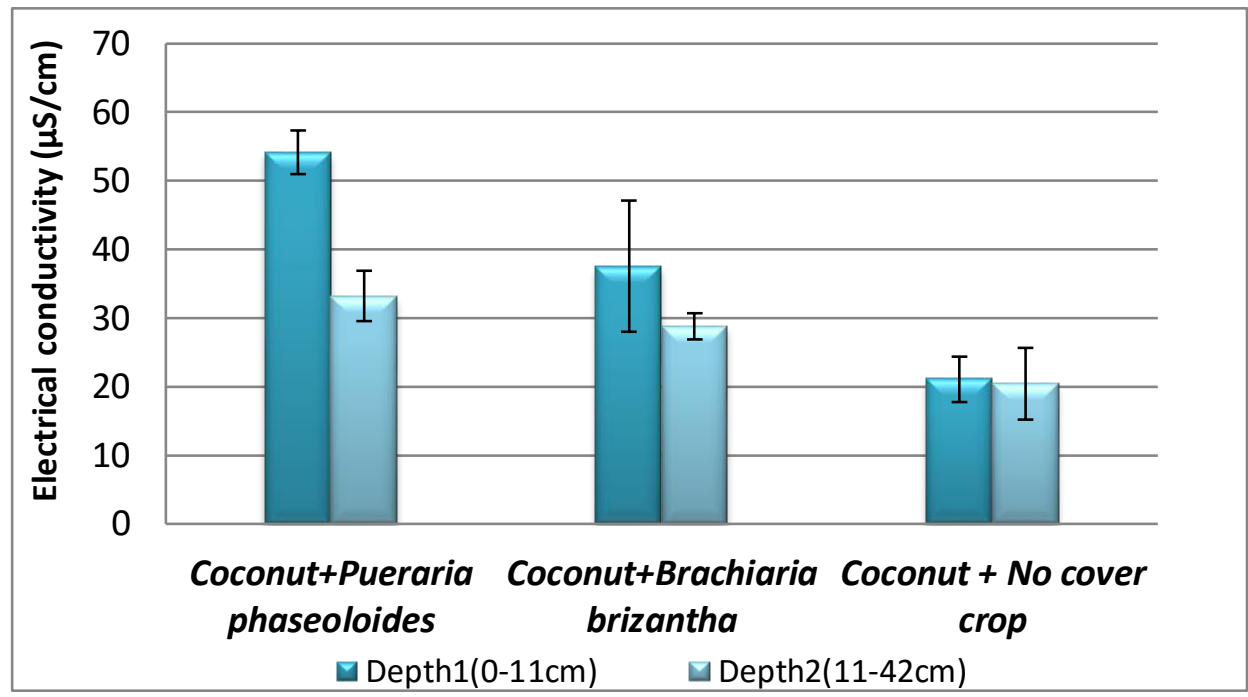

Figure 4. Electrical conductivity of the soils from different coconut + cover crop systems

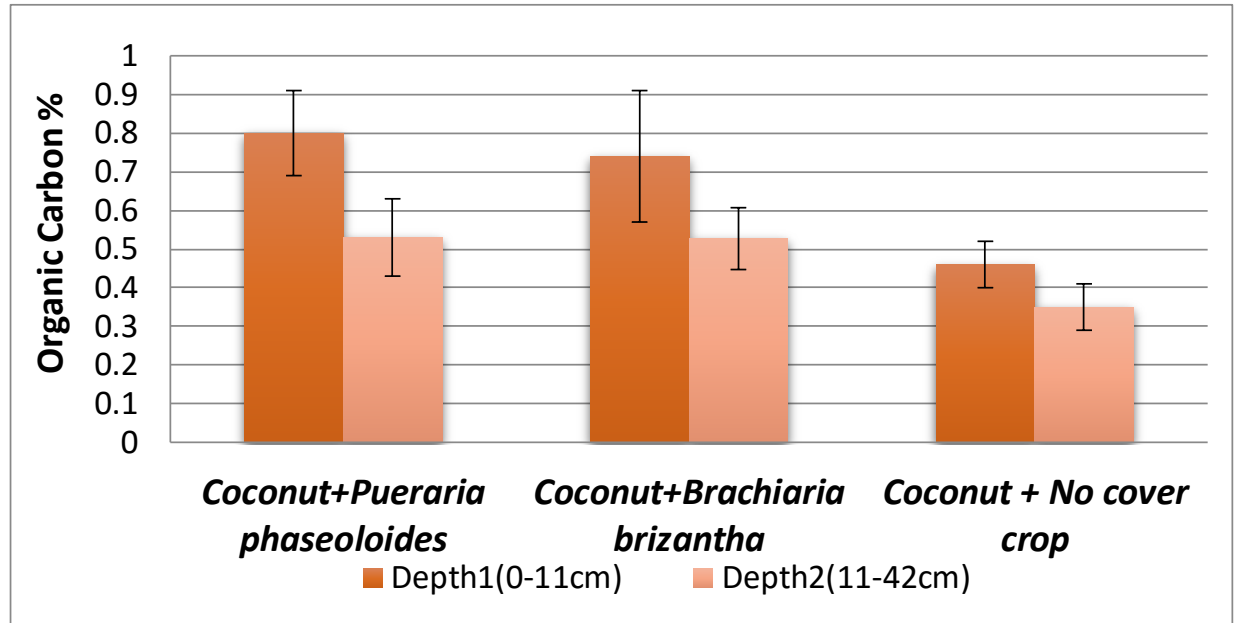

Figure 5. Mean soil organic carbon content from different coconut + cover crop systems 
compared to other two treatments (Table 2). Coconut-grown soil without a cover crop reported the lowest fungal colony counts. However, there was no significant difference among the treatments with respect to the enumerated fungal population. Cover crops have increased mycorrhizal fungus activity promoting a symbiotic relationship with the host plants' roots for water and nutrient uptake (Hoorman, 2009). Furthermore, it has been reported that 10,000 times more microbes are located in the rhizosphere next to the root than in bare soil (Hoorman, 2009). If the samples were collected from the rhizosphere there might be a significant difference in the results.

An increased microbial respiration rate was observed in soils from coconut + cover crop systems compared to the control (coconut + no cover crop; Figure 6). Coconut $+P$. phaseoloides system showed the highest $\mathrm{CO}_{2}$ evolution $1.54 \mathrm{mg} \mathrm{CO} /$ day because of the associated higher bacteria and fungi populations. Pueraria phaseoloides is a legume plant and plant matter from it has a $\mathrm{C}: \mathrm{N}$ ratio, which is

Table 2. Bacterial and fungal colony counts in soil samples from different coconut + cover crop systems

\begin{tabular}{lcc}
\hline Treatment & $\begin{array}{c}\text { Soil bacterial } \\
\text { population* } \\
\text { CFU/g }\end{array}$ & $\begin{array}{c}\text { Soil fungal } \\
\text { population* } \\
\text { CFU/g }\end{array}$ \\
\hline Coconut + Pueraria phaseoloides & $19.76 \times 10^{5} \mathrm{a}$ & $7.31 \times 10^{3 \mathrm{a}}$ \\
Coconut + Brachiaria brizantha & $13.41 \times 10^{5 \mathrm{~b}}$ & $6.06 \times 10^{3 \mathrm{a}}$ \\
Coconut + No cover crop & $7.65 \times 10^{5 \mathrm{c}}$ & $5.54 \times 10^{3} \mathrm{a}$ \\
\hline Means indicated by same superscript letters within a column are not significantly different at $p=0.05$
\end{tabular}

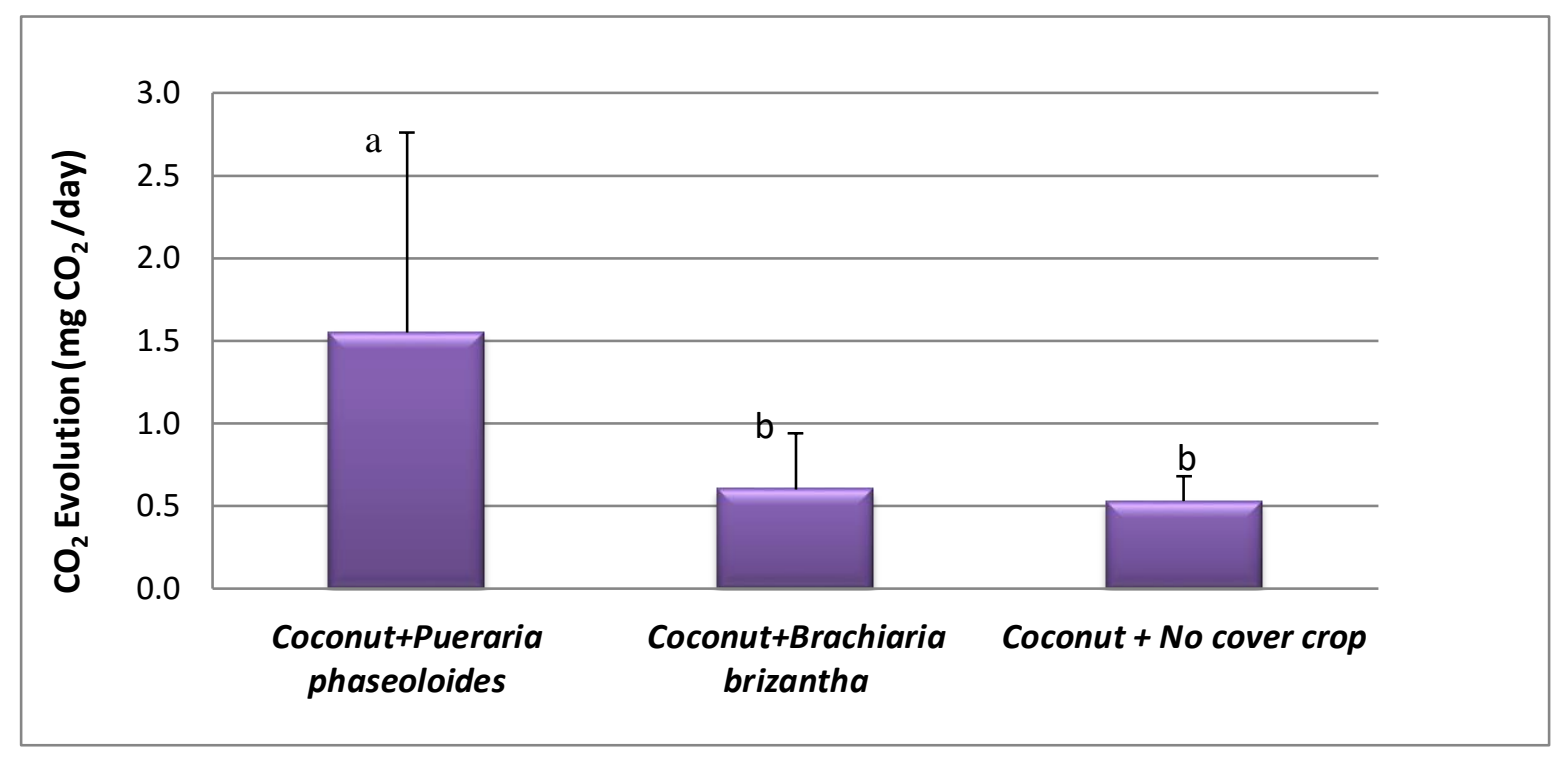

Figure 6. Microbial respiration rate in the soils from different coconut + cover crop systems 
favourable for the growth of bacteria and fungi. There was no significant difference $(\mathrm{p}>0.05)$ between Coconut + B. brizantha and the control systems. Control soils resulted a lower microbial respiration rate (0.53 $\mathrm{mg} \mathrm{CO}_{2} /$ day) due to its low density of microbial population (Table 2 and Figure $6)$.

\section{CONCLUSION}

The overall results show that coconut lands with cover crops have improved soil health and soil fertility in comparison to coconutgrown lands without cover crops within the same soil type (Red Yellow Podzolic) as indicated by most of the soil properties such as organic carbon content, aggregate stability, bacteria and fungi population and soil microbial activity. Among the cover crops of Pueraria phaseoloides and Brachiaria brizantha, P. phaseoloides showed a significant improvement in soil organic carbon content which is considered as a key factor for improving overall soil quality. Furthermore, the ability of Pueraria sp. to fix atmospheric nitrogen is an added advantage in improving soil fertility. However, lowering of soil $\mathrm{pH}$ and its effect on availability of other nutrients under $P$. phaseoloides needs further investigations.

\section{REFERENCES}

Anderson, T.M. and Ingram, J.S. (1989). Tropical Soil Biology and Fertility: A Handbook of Methods. C.A.B International.

Arshad, M.A., Lowery B. and Grossman, B.
(1996). Physical tests for monitoring soil quality. In: J.W. Doran and A.J. Jones (Eds). Methods for Assessing Soil Quality. Madison, WI.

Blake, G. R. and Hartge, K. H. (1986). Bulk density. In: Klute A. (Ed). Methods of Soil Analysis. Soil Science Society of America, Madison, WI.

Coconut Research Institute (2012). Cover crops in coconut land. Available from: http://www.cri.gov.lk/. (Accessed: 19 January 2014).

De Silva, M. (1961). Ceylon Coconut Planters Review. Available from: cri.nsf.ac.lk/bitstream/1/697/1/COCO PR-2 (1-2)-17.pdf. (Accessed 19 January 2014).

Hoorman, J. (2009). Using Cover Crops to Improve Soil and Water Quality. In: Agriculture and Natural Resources. The Ohio State University, USA.

Jayakody, J. A. D. S. S., Tennakoon, N. A. and Fernandopulle, M. N. D. (2007). Available soil phosphorus in coconut plantations in Boralu and Pallama soil series under different fertilizer regimes in Gampaha District of Sri Lanka. Cocos, 18: 31-44.

Loganathan, P., Dayatathne, P. M. N. and Shanmuganathan, R. T. (1984). Evaluation of the phosphorus status of some coconut growing soils of Sri Lanka. Cocos, 5: 29-43.

Mapa, R. B., Dassanayake, A. R. and Nayakekorale, H. B. (2005). Soils of the Intermediate Zone of Sri Lanka. Special publication, No. 4. Survodaya Vishva Lekha, Ratmalana, Sri Lanka.

Nelson, D. W. and Sommers, L. E. (1982). Total carbon, organic carbon and 
organic matter. In: Methods of Soil Analysis. American Society of Agronomy, Madison.

Nimmo, J. R. and Perkins, K. S. (2002). Aggregate stability and size distribution. In: Methods of Soil Analysis. American Society of Agronomy, Madison.

Tennakoon, N. A. (1990). Goat manure as a soil ameliorant and yield stimulant in coconut. Cocos, 8: 26-32. 